\title{
RECENZJE
}

Klio. Czasopismo poświęcone dziejom Polski i powszechnym

PL ISSN 1643-8191, t. 29 (2)/2014, s. 205-259

\section{Agnieszka Bartoszewicz, Piśmienność mieszczańska \\ w późnośredniowiecznej Polsce, Wydawnictua Uniwersytetu Warszawskiego, Warszawa 2012, ss. 348}

\section{(c) $(1)$}

http://dx.doi.org/10.12775/KLIO.2014.026

Kultura piśmienna w miastach średniowiecznych w Polsce najczę\ściej była przedmiotem badań archiwoznawczych. Wynikało to przede wszystkim z tego, że zachowane źródła miejskie w dominującej części są wytworami kancelarii miejskich na różnych etapach jej rozwoju. Zdecydowanie rzadsze są prace poświęcone innym świadectwom piśmiennicta miejskiego, np. historiografii miejskiej, tworzonej zresztą często również w kręgu osób związanych z kancelariami miejskimi, co wynika ze skromnej liczby tego rodzaju zabytków. W ostatnich latach nastąpiło ożywienie badań nad piśmiennością w średniowieczu w Polsce. Poddano je nowemu kwestionariuszowi badawczemu uwzględniającemu w większym zakresie kontekst społeczny funkcjonowania pisma $\mathrm{w}$ różnych środowiskach i traktujący słowo pisane w kategoriach komunikacji społecznej (por. prace A. Adamskiej, H. Manikowskiej i innych). Recenzowana książa wpisuje się zarówno w nurt prac archiwoznawczych, jak i badań z historii społecznej, wykorzystujących metody badawcze dotyczące komunikacji społecznej czy doświadczenia badań nad kształtowaniem elit społecznych i innych grup społecznych. Bartoszewicz zadaje pytanie o funkcje pisma w społeczeństwach miast polskich i jego rolę w komunikacji społecznej, skupia się na znaczeniu kulturowym pisma, a jednocześnie traktuje wytwory kultury 
piśmienniczej jako świadectwa określonego etapu rozwoju miast. Bardzo dokładnie analizuje grupę ludzi operujących pismem.

Praca została podzielona na pięć rozdziałów. Trzy z nich (I, III i IV) zostały poświęcone ludziom zajmującym się słowem pisanym w miastach. Pozostałe dotyczą w przeważającej części wytworów piśmiennictwa miejskiego. W rozdziale I noszącycm tytuł „Środowiska piszące w polskich miastach późnego średniowiecza” A. Bartoszewicz skupiła się na kwestiach związanych ze znaczeniem wykształcenia w środowiskach miejskich, jego etapami, znaczeniem wykształcenia i znajomości pisma w budowaniu indywidualnej kariery. Autorka prezentuje dosyć optymistyczny obraz środowisk znających pismo. Nie ulega wątpliwości, że posługiwanie się pismem i wykształcenie ułatwiały budowanie kariery. Nie zapomina jednak, że było wielu wykształconych ludzi, którym nie udało się zrobić żadnych znaczących karier. Wystarczy wykorzystać metryki uniwersyteckie, żeby wskazać wiele takich osób. Ta grupa pisarzy poddana została pogłębionej analizie w rozdziale dotyczącym „profesjonalistów słowa pisanego”. Wydaje się jednak, że nieco zaniedbana została kwestia pochodzenia różnych pisarzy, w tym zwłaszcza w zasadzie pominięte zagadnienie pochodzenia etnicznego. Zwraca uwagę fakt, że np. w kancelarii Krakowa funkcjonowała spora liczba pisarzy pochodzenia niemieckiego. Wymowna jest obecność wielu pisarzy niemieckich piszących w księgach również w języku niemieckim nawet w takich miastach, jak Przemyśl (s. 138). Za niezbyt szczęśliwe należy uznać sformułowane w tym rozdziale stwierdzenie „analfabeci prawdopodobnie także potrafili liczyć" (s. 43, przyp. 51).

Rozdział II został poświęcony wytworom kancelarii miejskich. Autorka poddała analizie pojawiające się w różnych miastach pierwsze księgi i - jako etap dalszego rozwoju kancelarii - serie ksiąg. Zarysowała znany również z innych miast rozwój wytwarzanych ksiąg od tych wczesnych, pojedynczych, zawierających zapiski o bardzo różnorodnym charakterze po księgi prowadzone przez poszczególne urzędy - radzieckie, ławnicze i wójtowsko-ławnicze, rachunkowe miejskie i prywatne, księgi przyjęć do prawa miejskiego, czy księgi testamentowe. W ramach analizy poszczególnych kategorii ksiąg przedstawiona została ich zawartość, rodzaje zapisywanych spraw, dla niektórych miast, w pierwszym rzędzie Krakowa, opracowane zostały dla ksiagg ławniczych i radzieckich również statystyczne obliczenia 
ukazujące liczbę poszczególnych rodzajów spraw i ich procentowy stosunek. W przypadku ksiag radzieckich dominowały sprawy finansowe. Osobny podrozdział został poświęcony dokumentom i listom. W odniesieniu do analizy krakowskich spraw kryminalnych i spisów proskrybowanych warto byłoby uwzględnić pracę M. Schüsslera*. W związku z analizą historiografii tworzonej w kręgu kancelarii miejskich trudno zgodzić się z twierdzeniem, że charakterystyczne dla niemieckiej historiografii mieszczańskiej były krótkie jedno- dwuzdaniowe zapiski (s. 123, przyp. 486). Wystarczy zwrócić uwagę na miejskie źródła narracyjne publikowane w serii „Deutsche Stadtchroniken”. Ciekawe jest spostrzeżenie autorki, że znaczna część zapisek historiograficznych miast polskich koncentrowała się na memorii dynastycznej (s. 124).

W rozdziale III poświęconym pisarzom miejskim skupiono się na pierwszych pisarzach w miastach, pisarzach poszczególnych urzędów miejskich, kwalifikacjach pisarzy, ich zarobkach, prestiżuzawodu. Jak zauważyta A. Bartoszewicz w odniesieniu do nazwisk na listach pisarzy miejskich, pierwsze wzmianki na temat kierowników kancelarii miejskich dotyczą osób duchownych. W dalszych analizach autorka skoncentrowała się na duchownych pełniących jednocześnie funkcje pisarzy miejskich w późniejszym okresie, nie zajmując się dokładniej tym zagadnieniem. Wydaje się, że warte rozważenia byłoby powiązanie początków kancelarii miejskich i ich personelu z osobami duchownymi funkcjonującymi w mieście, również w kontekście usług religijnych duchowieństwa na rzecz rad miejskich. Rady były nie tylko urzędami administracyjnymi zarządzającymi miastami, ale również korporacjami religijnymi ze wszystkimi konsekwencjami tego faktu. Rady budowały swój władczy autorytet poprzez sakralizację swojej pozycji w mieście**. Osoby prowadzące kancelarię miejską, będące jednocześnie duchownymi, mogły spełniać więc wiele funkcji religijnych wobec członków rady (msze korporacyjne, dbanie o memorię, pochówki), co miało również konsekwencje dla piśmiennictwa miejskiego. Przy istniejącej

M. Schüssler, Verbrechen in Krakau, 1361-1405, und seiner Beistadt Kasimir, 1370-1402, „Zeitschrift der Savigny-Stiftung für Rechtsgeschichte“, Germanistische Abteilung 1998, Bd. 115, s. 198-338.

** D. W. Poeck, Rituale der Ratswahl, Köln 2003. 
skąpej bazie źródłowej badania takie w znacznej mierze powinny mieć charakter porównawczy.

Inne zagadnienie stanowi różnorodność rąk w przypadku ksiąg $\mathrm{z}$ mniejszych miast. Wyróżnianie wielu różnych rąk pisarskich w przypadku ksiąg z mniejszych miast z jednej strony świadczyć może o braku zatrudnienia stałego pisarza, jest jednak również świadectwem tego, że funkcjonowało w takich miastach wiele osób, które posługiwały się pismem (s. 137). Widać jednak wyraźnie - na podstawie obserwacji autorki - zjawisko postępującej profesjonalizacji działalności kancelarii miejskich. Jak zauważyła Bartoszewicz, ostatnie dziesięciolecia XV wieku były okresem prawie pełnego przejęcia prowadzenia ksiąg miejskich przez stałych pisarzy. Chyba trudny do zweryfikowania jest wniosek, że synowie pisarzy wybierali kariery typowo miejskie w handlu lub w rzemiośle, nie chcieli naśladować karier swoich ojców. Zapewne osiągnięcie stanowiska pisarza miejskiego nie zawsze było tak łatwe (s. 170). Wydaje się, że należałoby tu przeprowadzić pogłębione badania, uwzględniające aspekt chronologiczny i zmieniający się prestiż zawodu w różnych ośrodkach miejskich, przy czym nie zawsze ów prestiż z upływem kolejnych dziesięcioleci musiał być mniejszy (tak zdaje się twierdzić autorka na s. 191). Kraków wydaje się w tym kontekście specyficznym ośrodkiem ze względu na obecność dworu królewskiego i możliwość zatrudnienia na dworze i uniwersytecie.

Rozdział IV „Profesjonaliści słowa pisanego” dotyczy ludzi wykonujących zawód pisarza, stanowiących niższy personel urzędów miejskich, a także pisarzy świadczących usługi mieszczanom, a nie urzędom. Wyróżniono tutaj kilka kategorii owych profesjonalistów, są tu więc m.in. ministerialis civitatis, zastępcy sądowi, notariusze publiczni, zatrudnieni w kancelariach, a także np. prywatni pedagodzy.

Najbardziej różnorodny charakter ma rozdział $\mathrm{V}$ „Pismo w życiu mieszczan”. Skupiono się w nim na pismach, które powstawały za sprawą zapotrzebowania ze strony mieszczan. Są to nie tylko rejestry handlowe, czy dokumenty i listy, ale także książki odpisywane na zamówienie mieszczan. W przypadku tego ostatniego zagadnienia warto by zwrócić również uwagę na prywatne zbiory kodeksów prawniczych, które były w posiadaniu niektórych urzędników miejskich. Osobne zagadnienia poruszone przez au- 
torkę stanowią kwestie piśmienności wśród kobiet oraz używania języków wernakularnych.

Powyższe uwagi, tylko w pewnym stopniu mające charakter krytyczny, w znacznej części wynikają raczej z inspiracji po lekturze opracowania A. Bartoszewicz. Narzucenie sobie ograniczenia w postaci skupiania się na funkcjonalnych kategoriach pisma w mieście w kontekście kancelaryjnym i urzędniczym, jak się wydaje, zawęziło nieco niektóre analizowane tematy. Można by zwrócić nieco więcej uwagi na funkcjonowanie niektórych ludzi słowa pisanego, zarówno w środowiskach kancelaryjnych miast, jak i w sferze religijnej. Wydaje się, że sygnalizowane we wstępie kategorie memoratywne znaczenia pisma powinny skłonić autorkę również do takiego kontekstu poruszanych zagadnień. Nie zmienia to faktu, że praca A. Bartoszewicz imponuje zakresem kwerendy źródłowej, operowaniem olbrzymim materiałem prozopograficznym dotyczącym osób posługujących się pismem w miastach polskich oraz różnorodnością poruszanych wątków. Bez wątpienia monografia ta stanie się lekturą obowiązkową nie tylko dla wszystkich badaczy zajmujących się szeroko rozumianą problematyką piśmiennictwa miejskiego, ale także dla badaczy innych zagadnień dotyczących życia miejskiego, chociażby życia codziennego w miastach i miejskiej kultury materialnej. I co najważniejsze, praca ta inspiruje do stawiania kolejnych pytań dotyczących kultury słowa pisanego w średniowieczu i na progu czasów nowożytnych.

Piotr Oliński (Toruń) 